\title{
HISTOLOGICAL CHARACTERIZATION OF Sticholecitha serpentis Prudhoe, 1949 (DIGENEA, BIERIIDAE, STICHOLECITHINAE), PARASITE OF Bothrops moojeni Hoge, 1966 (SERPENTES, VIPERIDAE)
}

SILVA TB. (1), ROSSELLINI M. (1), DAL PAI SILVA M. (2), SILVA RJ. (1)

(1) Department of Parasitology, Institute of Biosciences, São Paulo State University, UNESP, Botucatu, São Paulo, Brazil; (2) Department of Morphology, Institute of Biosciences, São Paulo State University, UNESP, Botucatu, São Paulo, Brazil.

ABSTRACT. The aim of this study was to evaluate the morphology of the species Sticholecitha serpentis Prudhoe, 1949 by means of histological procedures. Helminths were previously fixed in Railliet \& Henry solution, uncompressed and were included in 2-hydroxyethyl-methacrylate. Longitudinal and transverse serial sections with a 4- $\mu \mathrm{m}$ thickness were performed in a microtome (Leica RM 2165), stained with haematoxylin-eosin and then analyzed in a computerized image analysis system (Qwin Lite 2.5, Leica). Structures of systematic value, such as oral sucker, acetabulum, prepharynx, pharynx, esophagus, intestinal caeca, vitelline glands, ovary, uterus, cirrus pouch and testicles were described. Structures that were poorly visible in total preparations were also observed and described, such as efferent ducts, ejaculatory duct, prostate, seminal vesicle, seminal receptacle, Laurer's channel, Mehlis' gland, vitelline ducts, metraterm, genital atrium, digestive glands and excretory vesicle. We demonstrated that histological analysis can supply important data regarding the morphological characterization of $S$. serpentis and will be able to contribute to systematic studies of trematodes.

KEY WORDS: Sticholecitha serpentis, Digenea, Bothrops moojeni, Snakes, Brazil.

\section{CORRESPONDENCE TO:}

REINALDO JOSÉ DA SILVA, Departamento de Parasitologia, Instituto de Biociências, UNESP, Distrito de Rubião Júnior, Botucatu, São Paulo, Brasil, CEP 18618-000, Phone: +55-14-38116239, Fax: +55-14-38153744, Email: reinaldo@ibb.unesp.br 
T. B. Silva et al. HISTOLOGICAL CHARACTERIZATION OF Sticholecitha serpentis Prudhoe, 1949 (DIGENEA, BIERIIDAE, STICHOLECITHINAE), PARASITE OF Bothrops moojeni Hoge, 1966 (SERPENTES, VIPERIDAE). J. Venom. Anim. Toxins incl. Trop. Dis., 2005, 11, 4, p. 511

\section{INTRODUCTION}

Studies on the parasitology of Brazilian snakes have been carried out for some time. Travassos et al. (15) published an important review about trematodes from Brazil, but since this date few studies on trematodes of Brazilian snakes have been published. Artigas and Perez (2) performed a systematic review of the family Opisthogonimidae Freitas, 1756. Artigas and Campos (1) reported Plagiorchis luehei Travassos, 1927 to be a parasite of Hydrodynastes gigas Duméril, Bibron \& Duméril, 1854; Corrêa et al. (6) reported the occurrence of Ochetosoma heterocoelium Travassos, 1921 in Bothrops insularis Amaral, 1921. Silva et al. (13) found O. heterocoelium in a specimen of Chironius exoletus Linnaeus, 1758, and Silva and Barrella (12) reported the occurrence of Haplometroides odhneri Ruiz \& Perez, 1959 in Micrurus frontalis Duméril, Bibron \& Duméril, 1854. In addition, an important study was accomplished by Corrêa (5), in which all the systematic of snake trematodes parasites was reviewed.

The identification of trematodes has been based on descriptions of helminths fixed after compression. However, for some trematodes, the flattening techniques are unsatisfactory for the species characterization and the use of histological techniques is an alternative methodology that could contribute to the resolution of these problems (16).

Sticholecitha serpentis Prudhoe, 1949 is a species that has been poorly studied and its systematic is unclear $(2,5,15)$. Its occurrence has been reported only in Chironius carinatus Linnaeus, 1758 (9), Xenodon severus Linnaeus, 1758 (5) and Bothrops moojeni Hoge, 1966 (4). This helminth presents a dorsal longitudinal keel that hinders the observation of the internal structures after compression. Therefore, information on the morphology of this species could contribute to the systematic of this helminths group. The aim of this study was to describe the morphology of $S$. serpentis by means of histological procedures.

\section{MATERIAL AND METHODS}

The trematodes studied were collected from one B. moojeni (Serpentes, Viperidae) specimen, collected in a fauna rescue after the construction of the Sérgio Motta Hydroelectric Power Plant, in the Porto Primavera, São Paulo State, Brazil. These trematodes were previously fixed with Railliet-Henry solution, without compression 
T. B. Silva et al. HISTOLOGICAL CHARACTERIZATION OF Sticholecitha serpentis Prudhoe, 1949 (DIGENEA, BIERIIDAE, STICHOLECITHINAE), PARASITE OF Bothrops moojeni Hoge, 1966 (SERPENTES, VIPERIDAE). J. Venom. Anim. Toxins incl. Trop. Dis., 2005, 11, 4, p. 512

(4) and the voucher specimens of this helminth were deposited in the Coleção Helmintológica do Instituto de Biociências da Universidade Estadual Paulista (CHIBB-UNESP), Botucatu, State of São Paulo, Brazil.

The histological study was performed with previously fixed helminths that were included in 2-hydroxyethyl-methacrylate (7022 18500 Leica historesin embedding kit). Transverse and longitudinal serial sections with a $4 \mu \mathrm{m}$-thickness were made (Microtome Leica, model RM2165). These sections were stained with haematoxylineosin (HE) $(3,8)$ and then analyzed in a computerized image analysis system (QWin Lite 2.5 - Leica). The data were presented as mean (minimum-maximum) values.

\section{RESULTS}

The total length of the helminth observed in the longitudinal sections was of 7413.0 (6239.2-8125.3) $\mu \mathrm{m}$. The transverse sections showed varied morphology along the body. The largest width was 1588.0 (1390.8-1689.9) $\mu \mathrm{m}$ and the largest height was 1359.8 (1204.5-1489.9) $\mu \mathrm{m}$. The dorsal keel presented a height of 699.6 (619.1797.4) $\mu \mathrm{m}$ and width of 474.4 (266.2-654.7) $\mu \mathrm{m}$ (Figures 1-2).

The tegument (Figure 3) presented variable thickness along the body, measuring $13.9(9.9-19.6) \mu \mathrm{m}$. This is a continuous, acidophilic and homogeneous layer that covers the whole external surface of the helminth. The basophilic cellular bodies of the cells forming the tegument lie deep among the parenchyma cells. This tegument bears spines that present a length of 23.6 (20.5-27.4) $\mu \mathrm{m}$ and width of 4.8 (2.9-6.6) $\mu \mathrm{m}$ at the base. Under the tegument, a well-delimited clear area is observed, with a thickness of 3.7 (2.4-6.5) $\mu \mathrm{m}$, which is the basement membrane. Below this are two layers of smooth muscle cells: an external circular layer, with isolated muscular fibers, measuring $5.1(2.2-6.9) \mu \mathrm{m}$ in thickness, and an internal longitudinal with 3.9 (2.1-7.2) $\mu \mathrm{m}$ in thickness. The body is filled out by a parenchyma constituted of loose connective tissue.

The oral sucker (Figure 4-5) is subterminal, rounded, 626.9 (560.4-714.5) $\mu \mathrm{m}$ long, $638.4(614.7-662.1) \mu \mathrm{m}$ wide and $483.2(440.0-515.5) \mu \mathrm{m}$ high. It presents a fine tegument, with a thickness of 6.5 (4.4-12.2) $\mu \mathrm{m}$, without spines. Below this layer, the oral sucker presents a basement membrane, 2.3 (1.5-3.1) $\mu \mathrm{m}$ thick, and four layers of smooth muscle fibers: the first, is a fine circular layer, with a width of 3.0 (1.6-3.6) 
T. B. Silva et al. HISTOLOGICAL CHARACTERIZATION OF Sticholecitha serpentis Prudhoe, 1949 (DIGENEA, BIERIIDAE, STICHOLECITHINAE), PARASITE OF Bothrops moojeni Hoge, 1966 (SERPENTES, VIPERIDAE). J. Venom. Anim. Toxins incl. Trop. Dis., 2005, 11, 4, p. 513

$\mu \mathrm{m}$. The second, in a radial sense, presents a length of $103.9(90.7-124.2) \mu \mathrm{m}$, in a perpendicular position to the first layer, surrounded by loose connective tissue. The third layer is constituted of radial fibers, in a circular sense, with a thickness of 5.3 (2.3-7.3) $\mu \mathrm{m}$. After the third muscular layer, there is an area similar to the basement membrane, with a clear aspect and thickness of 2.2 (1.1-3.3) $\mu \mathrm{m}$ that communicates with the fourth muscular layer, in a circular manner, and presents a 2.9 (0.7-7.2) $\mu \mathrm{m}$ thickness. The thickness of these fibers increases towards the mouth area. Increases in the dimensions of the internal muscular layer in the extremities of the sucker are also observed. Another observation in the morphology of the oral sucker is the presence of a more developed internal musculature in the mouth area.

The mouth is formed by a cavity, with a length of 88.5 (63.8-113.2) $\mu \mathrm{m}$ and communicates the oral sucker with the prepharynx (Figure 6).

The prepharynx (Figure 6) may be characterized as an opening, 135.7 (78.1-175.6) $\mu \mathrm{m}$ long, with an irregular format, and presents a width of 105.2 (73.1-122.2) $\mu \mathrm{m}$ in the area closed to the mouth and width of 172.0 (112.3-206.9) $\mu \mathrm{m}$ near the pharynx. It is formed by a mucous layer, similar to the tegument, with a $9.8(4.7-22.6) \mu \mathrm{m}$ thickness, and two layers of smooth muscle: an internal circular layer, measuring 3.1 (1.1-4.9) $\mu \mathrm{m}$ thick, and a longitudinal layer, with a 3.3 (1.8-5.7) $\mu \mathrm{m}$ thickness.

The pharynx (Figure 7) is characterized as a circular structure, which is ovoid, measuring 251.5 (212.1-309.8) $\mu \mathrm{m}$ long and 282.2 (265.5-306.1) $\mu \mathrm{m}$ wide. It has a mucous layer similar to the tegument, with a 9.7 (5.3-16.2) $\mu \mathrm{m}$ thickness and four smooth muscular layers: the first, constituted of longitudinal muscular fibers, has a thickness of 7.1 (6.1-7.7) $\mu \mathrm{m}$; and the second is radial, perpendicular to the first one, with a length of 90.1 (68.4-114.7) $\mu \mathrm{m}$; the third has a circular sense, with a thickness of 5.4 (5.3-5.4) $\mu \mathrm{m}$; and the fourth, in a longitudinal sense, has a 4.4 (1.8-5.9) $\mu \mathrm{m}$ thickness.

The esophagus (Figures 8-9) is continuous to the pharynx, and extends until the acetabulum area, where it bifurcates. It measures 797.1 (706.6-854.7) $\mu \mathrm{m}$ long and $217.2(180.5-246.2) \mu \mathrm{m}$ wide. The mucous layer is acidophilic, similar to the tegument, quite sinuous, with a $9.2(5.7-18.6) \mu \mathrm{m}$ thickness and it is attached to the basement membrane, which measures 1.9 (1.7-2.3) $\mu \mathrm{m}$ in thickness. Under this layer, there is a circular smooth musculature, with muscle fibers that are 4.9 (1.6-9.6) 
T. B. Silva et al. HISTOLOGICAL CHARACTERIZATION OF Sticholecitha serpentis Prudhoe, 1949 (DIGENEA, BIERIIDAE, STICHOLECITHINAE), PARASITE OF Bothrops moojeni Hoge, 1966 (SERPENTES, VIPERIDAE). J. Venom. Anim. Toxins incl. Trop. Dis., 2005, 11, 4, p. 514

$\mu \mathrm{m}$ in diameter, and a longitudinal muscular layer, which is $9.9(6.5-12.1) \mu \mathrm{m}$ in thickness. In the initial portion, the esophagus lumen has a variable form. Some histological sections in stick format are observed in this region. In the posterior portion, before the division of the intestinal caeca, the lumen presents starry or "barball" forms.

Numerous groups of glandular cells lie in the parenchyma around the prepharynx, pharynx and esophagus. These glands decrease in amount as the esophagus divides in intestinal caeca, and then disappears (Figures 7-9).

The intestinal caeca (Figure 10) are tubular structures, with variable lumen, and extend until to the posterior region. The intestinal caeca mucous layer is formed by an epithelium with large and clear cells near more basophilic cells. Below this, there is an internal circular smooth muscular layer that is $2.2(1.8-3.4) \mu \mathrm{m}$ in thickness, and another with longitudinal muscular fibers, which is 4.0 (1.9-6.7) $\mu \mathrm{m}$ in thickness.

The excretory duct presents a "Y" form. The right branch of the excretory duct appears in the ovary area and the left branch in the area of the anterior testis. These branches are characterized by two short lateral channels, with a wide lumen and extremely irregular borders. Both channels merge in the testicles area and then extend until the posterior end of the helminth as a long duct. The excretory duct is covered by a squamous simple epithelium and ends in an excretory pore of the terminal position in the posterior end of the body (Figures 11-12).

The acetabulum (Figures 13-14) is ventrally located, a little above the equatorial area and presents a similar structure to that of the oral sucker, with a fine tegument, 6.2 (2.8-8.6) $\mu \mathrm{m}$ thickness, without spines. It presents a length of 797.1 (706.6-854.7) $\mu \mathrm{m}$, a width of 599.3 (538.1-633.2) $\mu \mathrm{m}$ and a height of 485.5 (450.6-511.1) $\mu \mathrm{m}$. It has four muscular smooth layers: the first is a fine longitudinal layer, 3.6 (2.5-4.9) $\mu \mathrm{m}$ in thickness; the second is constituted of radial muscular fibers, perpendicular to the first one, 116.4 (90.3-137.9) $\mu \mathrm{m}$ long; the third, formed by longitudinal musculature, is 12.9 (7.2-16.6) $\mu \mathrm{m}$ in thickness; and the fourth, a fine layer that covers the sucker internally, is 6.4 (4.7-7.6) $\mu \mathrm{m}$ in thickness. A well-developed circular musculature in the two acetabulum extremities is also observed.

The ovary (Figure 15) has an ovoid form and presents its larger axis in the longitudinal sense. It measures 346.0 (294.3-386.1) $\mu \mathrm{m}$ long and 347.3 (327.1-374.1) 
T. B. Silva et al. HISTOLOGICAL CHARACTERIZATION OF Sticholecitha serpentis Prudhoe, 1949 (DIGENEA, BIERIIDAE, STICHOLECITHINAE), PARASITE OF Bothrops moojeni Hoge, 1966 (SERPENTES, VIPERIDAE). J. Venom. Anim. Toxins incl. Trop. Dis., 2005, 11, 4, p. 515

$\mu \mathrm{m}$ wide. It is located in the dorsal region on the posterior extremity of the acetabulum, lightly displaced to the right margin. It is surrounded by a thin layer of connective tissue and shows cells in various differentiation stages. Surrounding this layer are small basophilic cells with relatively little cytoplasm, which are the oogonias. In the center there are larger cells, with polyhedral, ovoid or spherical forms, larger nuclei, an evident nucleolus and clear cytoplasm, which are the oocytes.

The Mehlis' gland (Figures 16 and 17) is lateral and ventral to the ovary, towards the center of the helminth. It is constituted by a group of cells with slightly basophilic cytoplasm, a big nucleus and visible nucleolus. The ootype (Figures 16-17) is observed in the center of this gland. It is an extensive duct with flattened cells that receives the vitelline ducts, seminal receptacle ducts and the beginning of the Laurer's channel (Figures 15-16).

The seminal receptacle with flattened cells (Figures 15-16) is lateral to the ovary, ovoid, 153.4 (138.0-167.4) $\mu \mathrm{m}$ long and 130.5 (100.6-150.3) $\mu \mathrm{m}$ wide. A large quantity of spermatozoids can be observed in the seminal receptacle.

The vitelline glands (Figure 18) are ovoids, with varied forms, lobulated, bunched, close amongst themselves, arranged in a single row, disposed in the dorsal keel of the body and are distributed from the esophagus-caeca transition area to the posterior testicle area. The lobes are formed by a group of polygonal cells, with central nucleus and cytoplasm full of basophilic granules, which contains vitellus.

The uterus (Figure 11 ) begins in the ootype area, extends posteriorly until the end of the body, presents many loops and then returns to the anterior region. It has a fine wall, constituted by flat cells and is filled with a large quantity of recently formed eggs, which contains a cell egg and some cells containing vitellus and surrounded by a thin peel. The uterus' wall thickens forming the metraterm in its final portion (Figure 17), which is surrounded with many gland cells. The metraterm (Figure 19) opens up at a genital atrium, close to the pore through which the cirrus pouch opens up.

The testicles (Figure 20) are structures of irregular forms and appear in the middle region of the body. The right testicle is anterior to the left. The anterior testicle presents a length of 478.7 (437.7-516.7) $\mu \mathrm{m}$ and width of 524.2 (468.2-563.9) $\mu \mathrm{m}$, and the posterior testicle is 475.3 (425.9-559.9) $\mu \mathrm{m}$ long and 427.8 (386.8-448.2) $\mu \mathrm{m}$ wide. The testicles are surrounded by a fine connective tissue layer, and soon after this layer, immature cells are observed (marginal germinative epithelium or 
T. B. Silva et al. HISTOLOGICAL CHARACTERIZATION OF Sticholecitha serpentis Prudhoe, 1949 (DIGENEA, BIERIIDAE, STICHOLECITHINAE), PARASITE OF Bothrops moojeni Hoge, 1966 (SERPENTES, VIPERIDAE). J. Venom. Anim. Toxins incl. Trop. Dis., 2005, 11, 4, p. 516

spermatogonias), which are distributed in groups. Spermatocytes, spermatids and spermatozoids are also observed in the testicle center (Figure 21).

Each one of the testicles has an efferent duct (Figure 22), which is characterized by a layer of smooth muscular tissue and a small lumen, 25.4 (22.5-27.6) $\mu \mathrm{m}$ in diameter. These ducts lead to the seminal vesicle, where they become a single duct inside the cirrus pouch (Figure 23).

The cirrus pouch (Figure 23) extends transversely to the median line and contains the seminal vesicle, the prostate glands, the ejaculatory duct and the cirrus. The seminal vesicle is in the posterior end of the cirrus pouch, presents a tubular structure, long and coiled, with an extensive lumen, 81.3 (71.8-93.6) $\mu \mathrm{m}$ in diameter, covered by a fine wall, and presents a large quantity of spermatozoids. The prostatic glands are diffuse glands formed by basophilic cells. The retracted cirrus is a long structure, thick-walled, unarmed, surrounded by numerous prostate glands. The cirrus pouch opens up at the genital atrium, close to the metraterm pore.

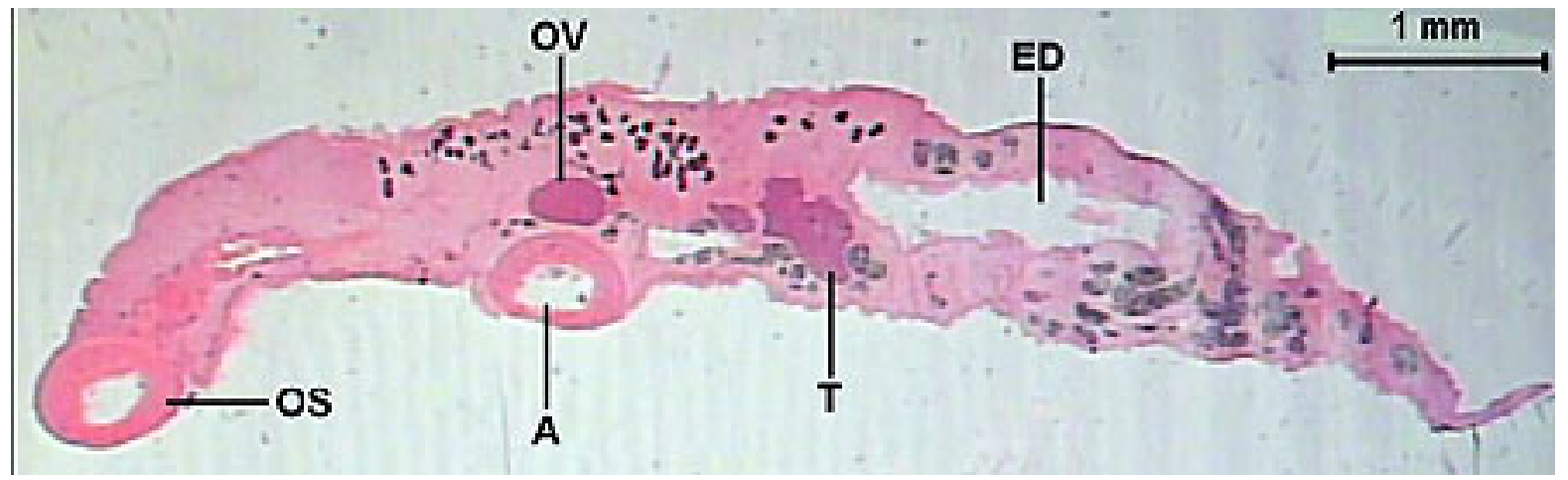

Figure 1. Longitudinal section of Sticholecitha serpentis. OV - ovary, ED - excretry duct, $\mathrm{T}$ - testicle, A - acetabulum, OS - oral sucker. HE. 
T. B. Silva et al. HISTOLOGICAL CHARACTERIZATION OF Sticholecitha serpentis Prudhoe, 1949 (DIGENEA, BIERIIDAE, STICHOLECITHINAE), PARASITE OF Bothrops moojeni Hoge, 1966 (SERPENTES, VIPERIDAE). J. Venom. Anim. Toxins incl. Trop. Dis., 2005, 11, 4, p. 517

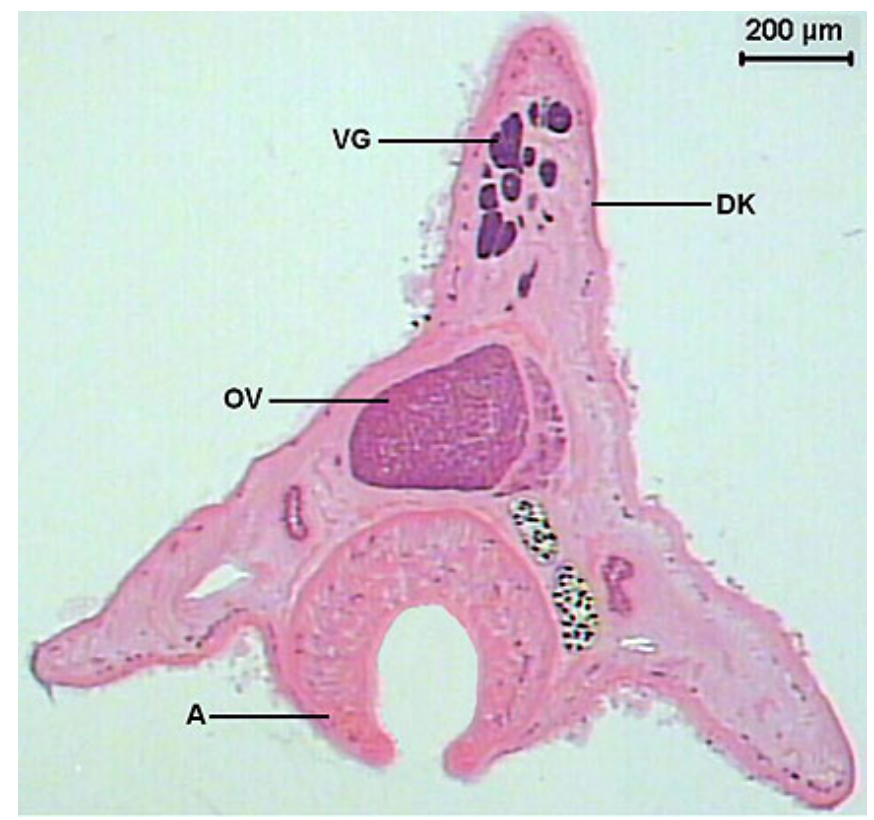

Figure 2. Transversal section of Sticholecitha serpentis. VG - viteline glands, DK dorsal keel, OV - ovary, A - acetabulum. HE.

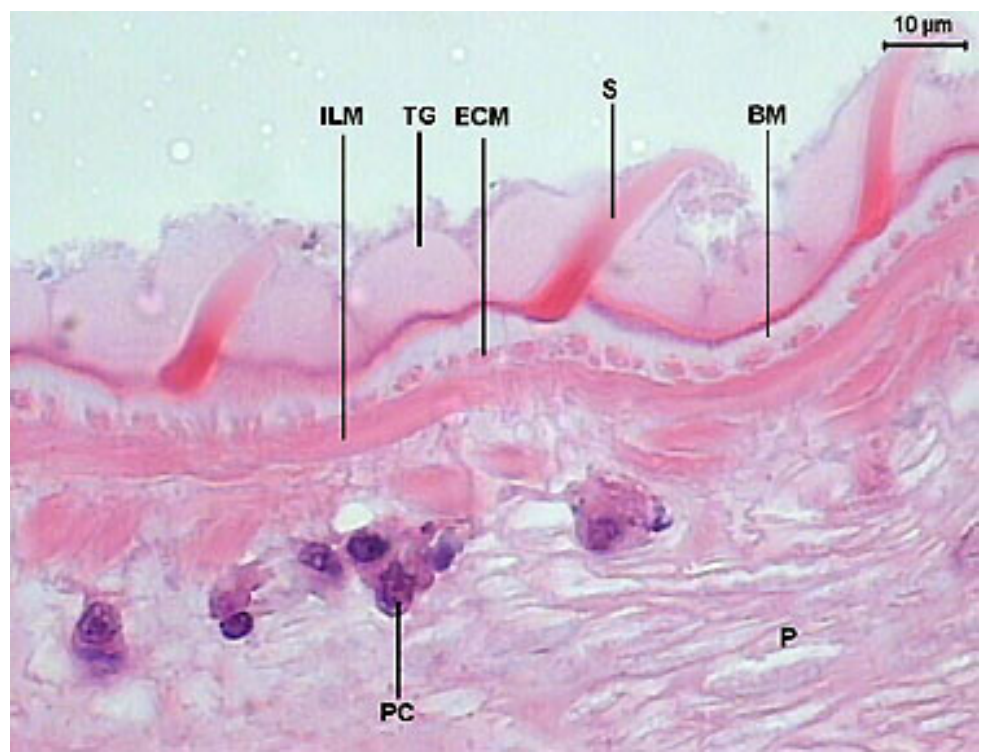

Figure 3. Longitudinal section of Sticholecitha serpentis. TG - tegument, BM - basement membrane, ECM - external circular musculature, ILM - internal longitudinal musculature, $\mathrm{P}$ - parenchyma, S - spines, PC - parenchymal cells. HE. 
T. B. Silva et al. HISTOLOGICAL CHARACTERIZATION OF Sticholecitha serpentis Prudhoe, 1949 (DIGENEA, BIERIIDAE, STICHOLECITHINAE), PARASITE OF Bothrops moojeni Hoge, 1966 (SERPENTES, VIPERIDAE). J. Venom. Anim. Toxins incl. Trop. Dis., 2005, 11, 4, p. 518

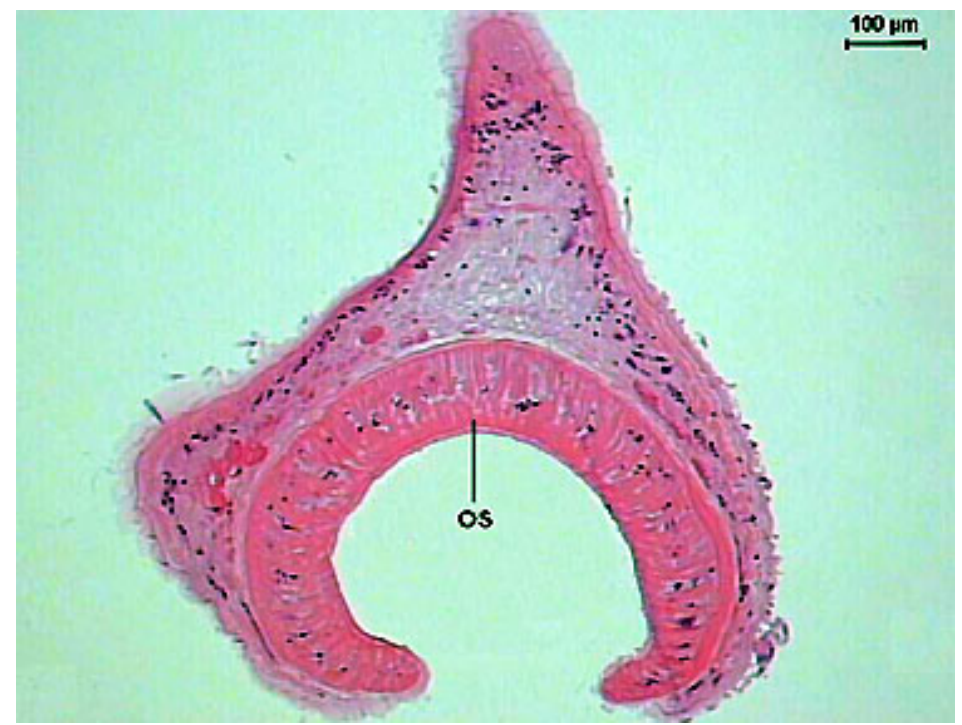

Figure 4. Transversal section of Sticholecitha serpentis. OS - oral sucker. HE.

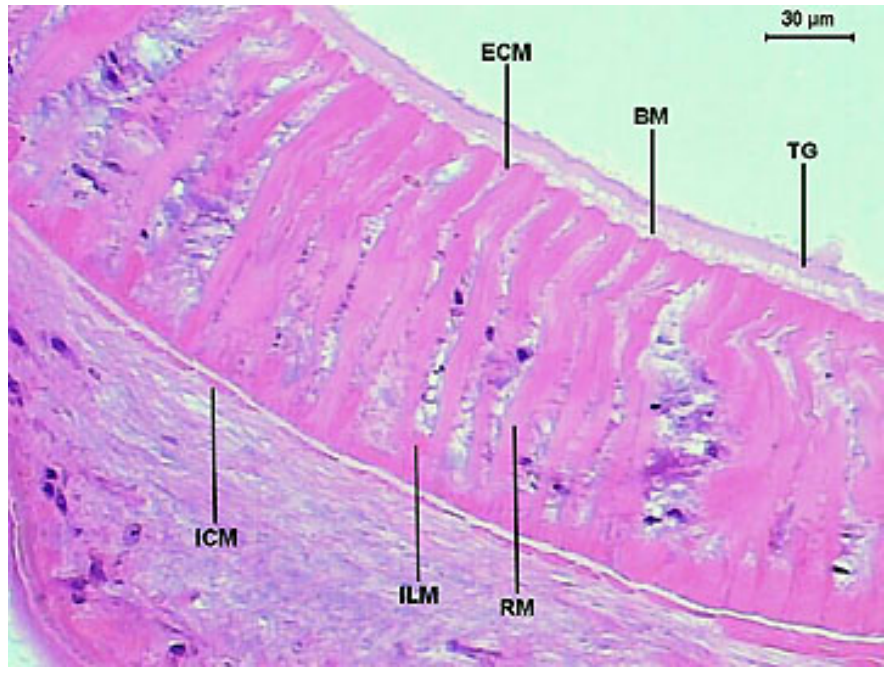

Figure 5. Detail of the Sticholecitha serpentis oral sucker. BM - basement membrane, ECM - external circular musculature, ICM - internal circular musculature, ILM - internal longitudinal musculature, RM - radial musculature, TG - tegument. HE. 
T. B. Silva et al. HISTOLOGICAL CHARACTERIZATION OF Sticholecitha serpentis Prudhoe, 1949 (DIGENEA, BIERIIDAE, STICHOLECITHINAE), PARASITE OF Bothrops moojeni Hoge, 1966 (SERPENTES, VIPERIDAE). J. Venom. Anim. Toxins incl. Trop. Dis., 2005, 11, 4, p. 519

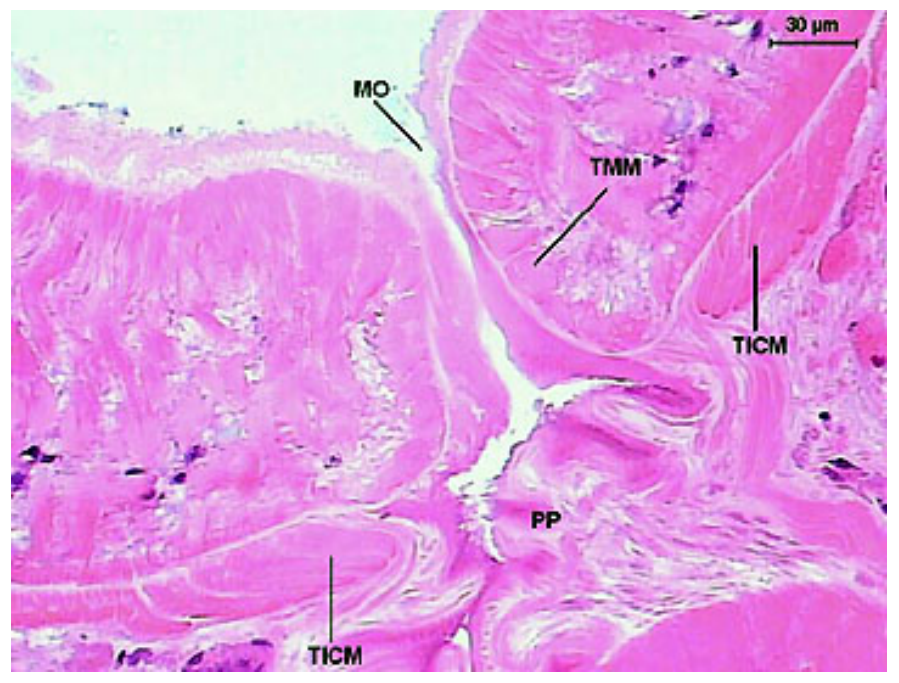

Figure 6. Longitudinal section of the mouth and prepharynx of Sticholecitha serpentis. M - mouth, PP - prepharynx, TMM - increased thickness of the mouth musculature, TICM - increased thickness of the internal circular musculature. HE.

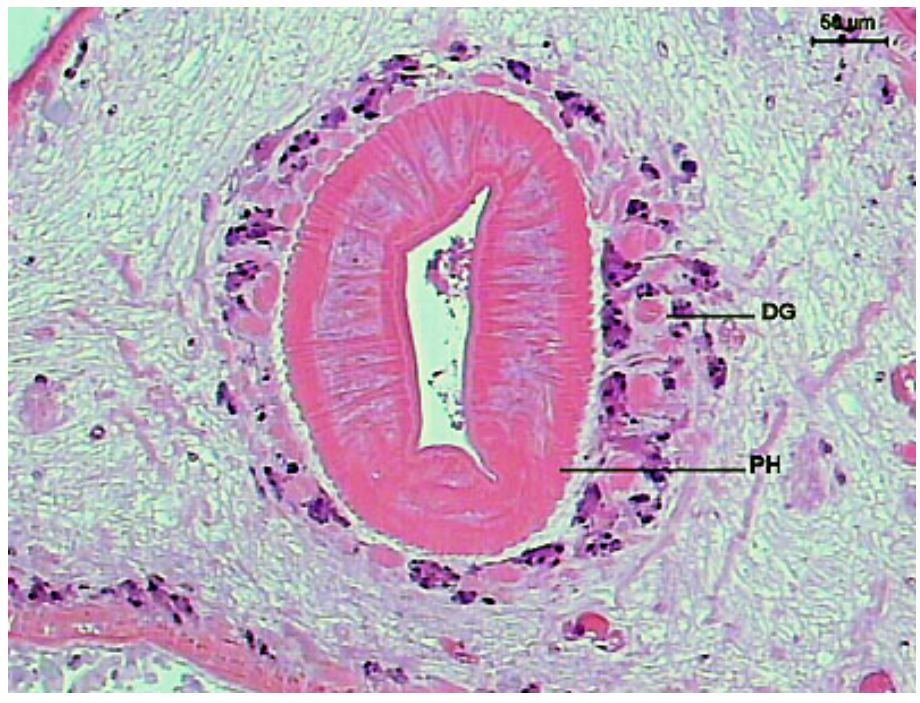

Figure 7. Transversal section of the pharynx $(\mathrm{PH})$ and digestive glands (DG) of Sticholecitha serpentis. HE. 
T. B. Silva et al. HISTOLOGICAL CHARACTERIZATION OF Sticholecitha serpentis Prudhoe, 1949 (DIGENEA, BIERIIDAE, STICHOLECITHINAE), PARASITE OF Bothrops moojeni Hoge, 1966 (SERPENTES, VIPERIDAE). J. Venom. Anim. Toxins incl. Trop. Dis., 2005, 11, 4, p. 520

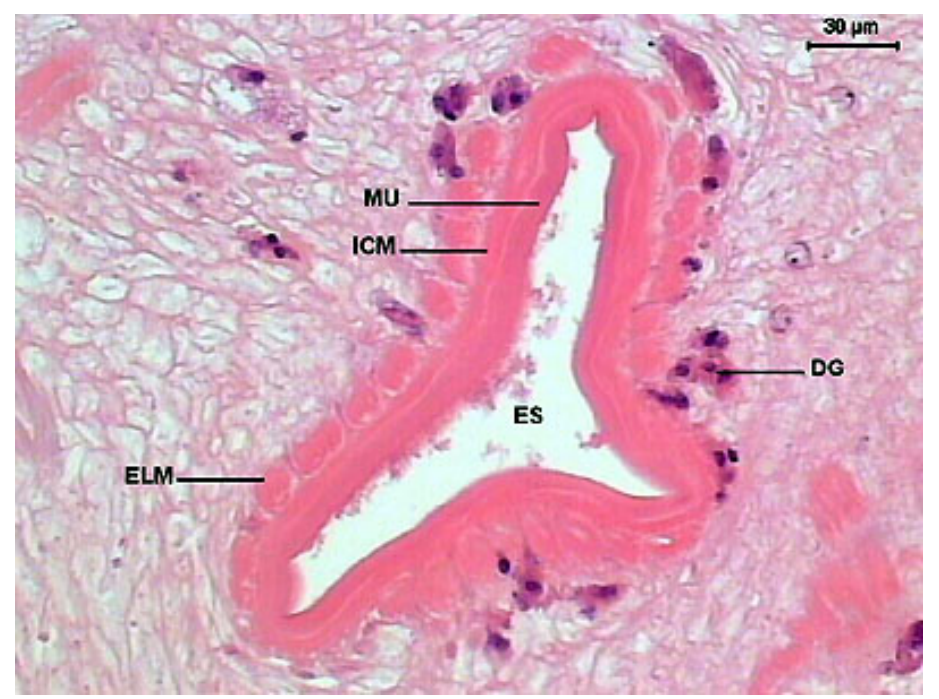

Figure 8. Transversal section of the initial portion of Sticholecitha serpentis esophagus. ES - esophagus, DG - digestive glands, MU - mucosa, ICM - internal circular musculature, ELM - external longitudinal musculature. HE.

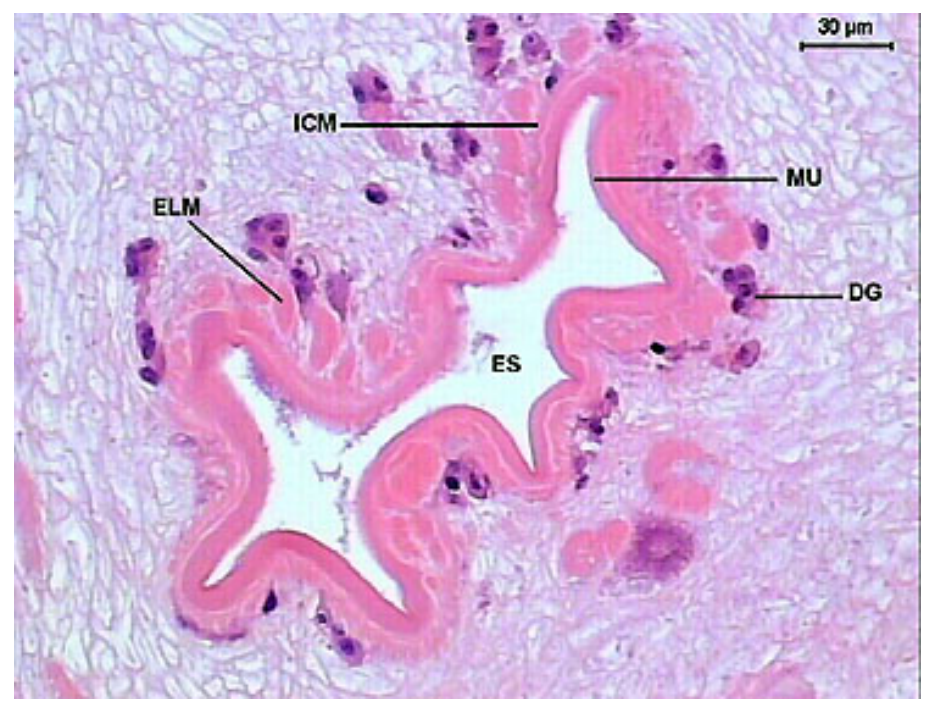

Figure 9. Transversal section of the final portion of Sticholecitha serpentis esophagus. ES - Esophagus, DG - digestive glands, MU - mucosa, ICM - internal circular musculature, ELM - external longitudinal musculature. HE. 


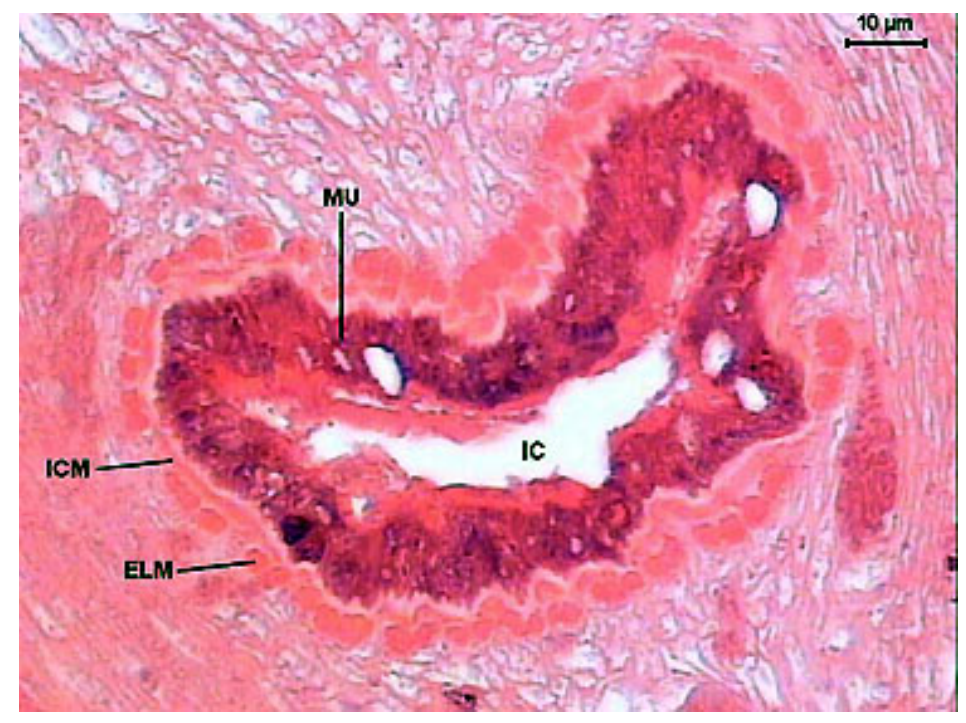

Figure 10. Transversal section of the Sticholecitha serpentis Intestinal caecum. IC intestinal caecum lumen, MU - mucosa, ICM - internal circular musculature, ELM external longitudinal musculature. HE.
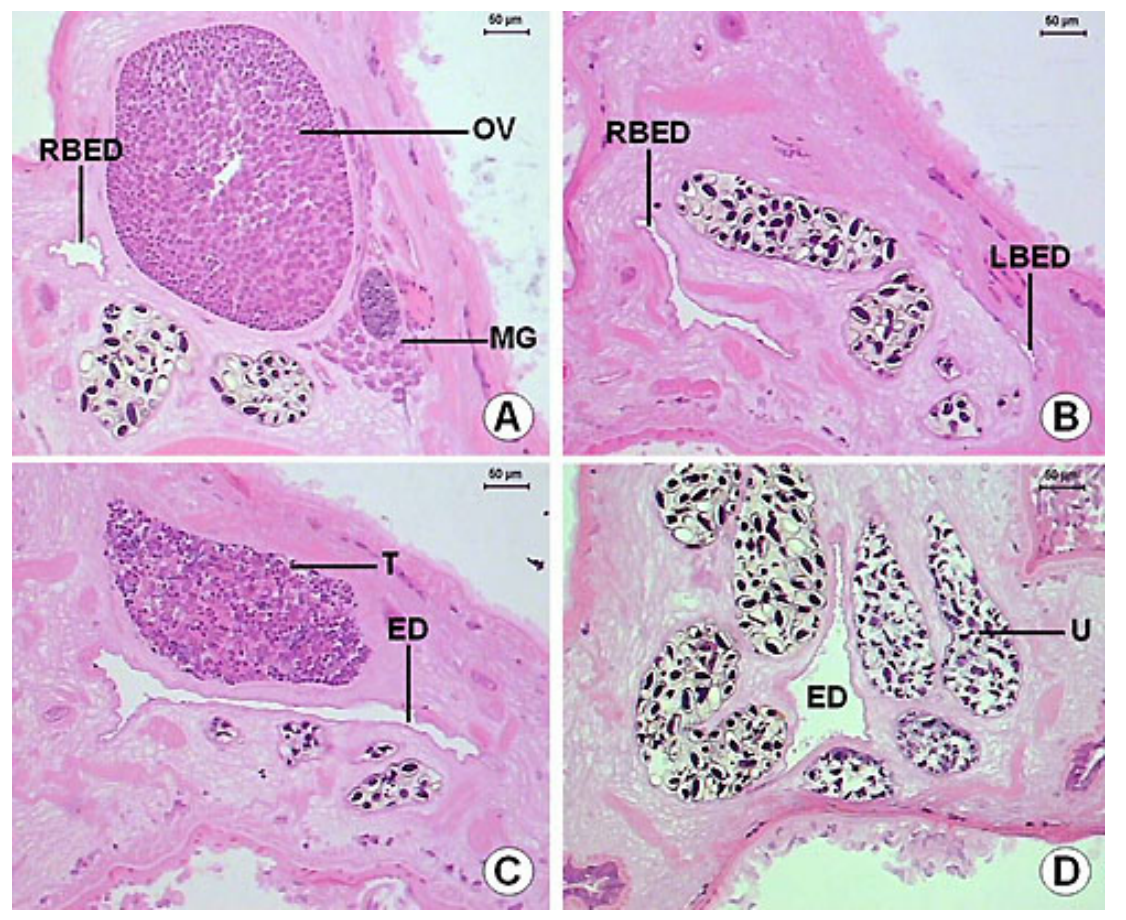

Figure 11. Transversal section of the excretory duct of Sticholecitha serpentis. A) beginning of the rigth brach of excretory duct in the ovary region, $B$ ) beginning of the left branch of excretory duct before the anterior testicle region, C) rigth and left branches merged in the testicle region, D) dorsal position of the excretory duct. ED excretory duct, T - testicle, MG - Mehlis' gland, LBED - left branch of excretory duct, RBED - rigth branch of excretory duct, OV - ovary, U - uterus. HE. 
T. B. Silva et al. HISTOLOGICAL CHARACTERIZATION OF Sticholecitha serpentis Prudhoe, 1949 (DIGENEA, BIERIIDAE, STICHOLECITHINAE), PARASITE OF Bothrops moojeni Hoge, 1966 (SERPENTES, VIPERIDAE). J. Venom. Anim. Toxins incl. Trop. Dis., 2005, 11, 4, p. 522
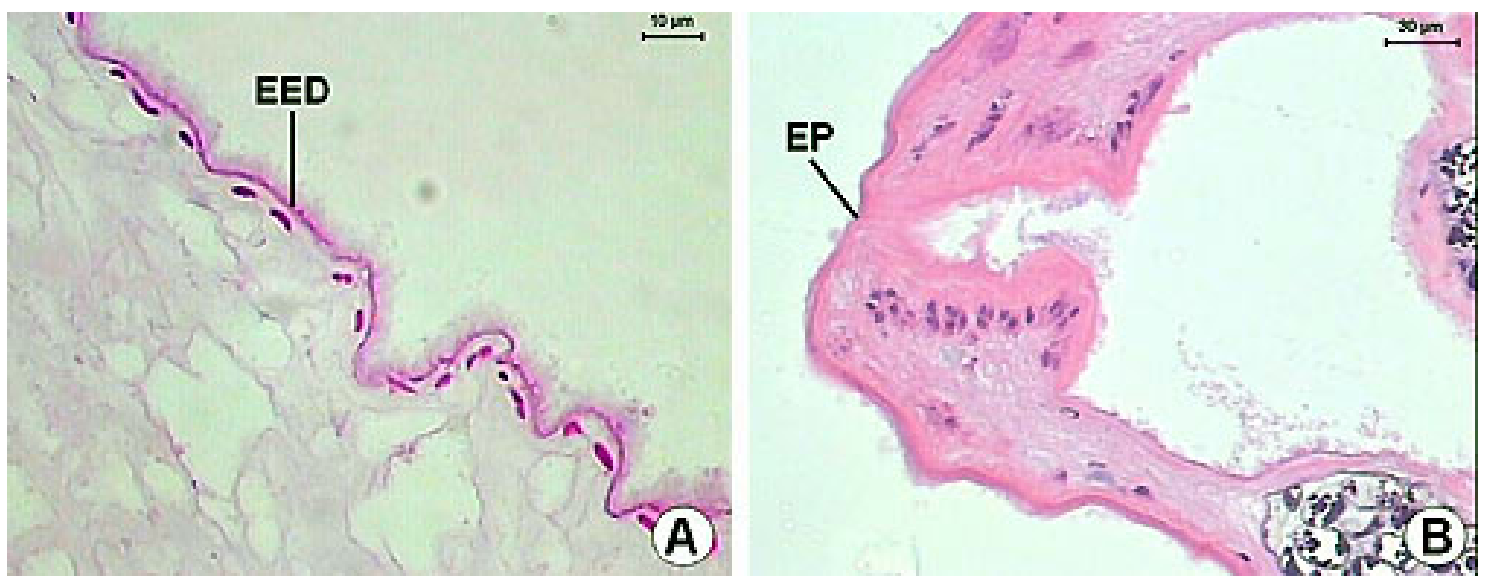

Figure 12. A-B) Longitudinal section of the excretory duct of Sticholecitha serpentis. EP - excretory pore, EED - epithelium of excretory duct. HE.

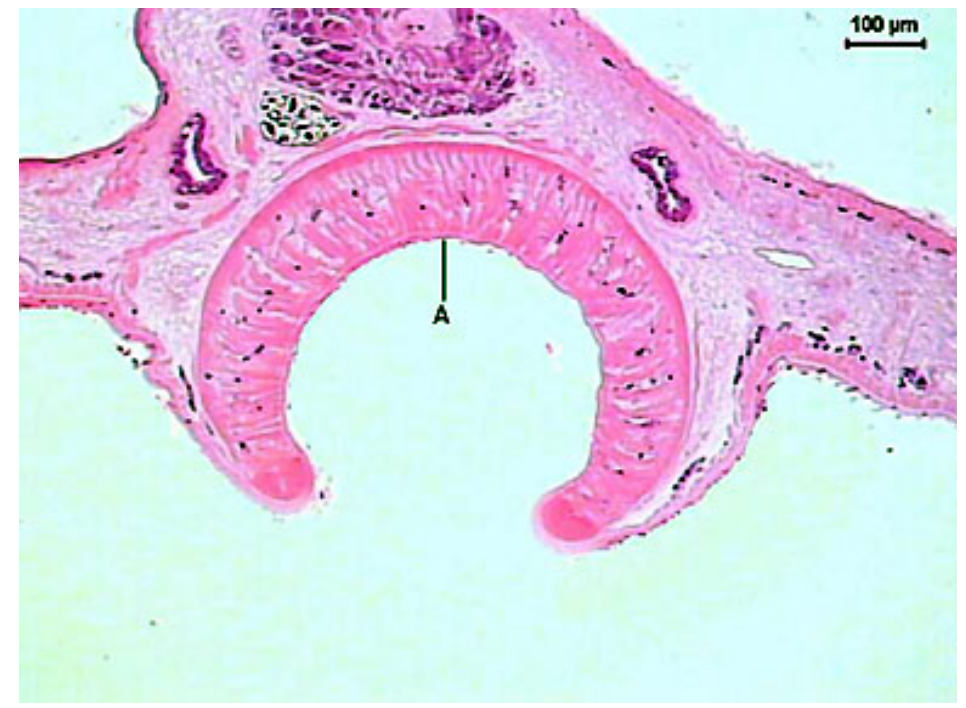

Figure 13. Transversal section of the Sticholecitha serpentis acetabulum (A). HE. 
T. B. Silva et al. HISTOLOGICAL CHARACTERIZATION OF Sticholecitha serpentis Prudhoe, 1949 (DIGENEA, BIERIIDAE, STICHOLECITHINAE), PARASITE OF Bothrops moojeni Hoge, 1966 (SERPENTES, VIPERIDAE). J. Venom. Anim. Toxins incl. Trop. Dis., 2005, 11, 4, p. 523

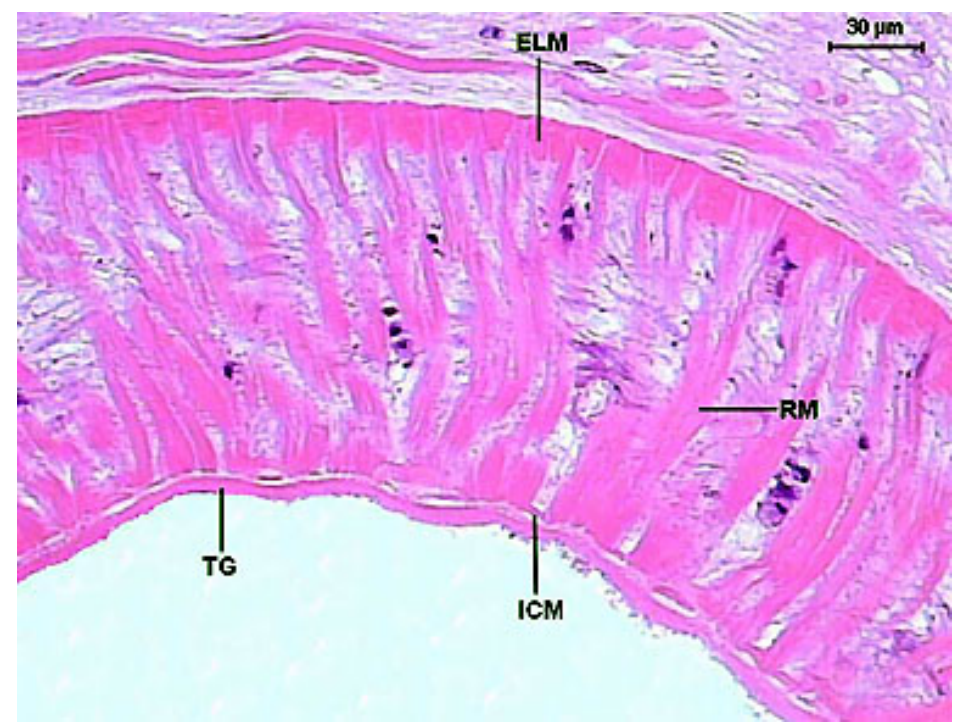

Figure 14. Detail of the Sticholecitha serpentis acetabulum. ELM - external longitudinal musculature, ICM - internal circular musculature, RM - radial musculature, TG - tegument. HE.

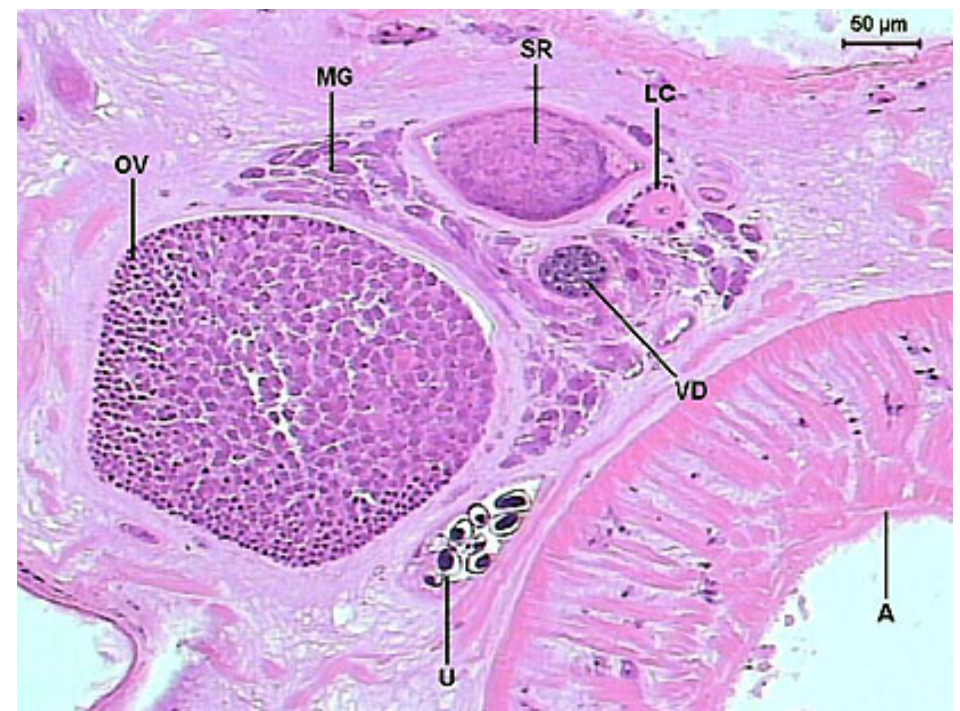

Figure 15. Transversal section of the ovary and Mehlis' gland of the Sticholecitha serpentis. MG - Mehlis gland, SR - seminal receptacle, LC - Laurer's channel, OV ovary, VD - vitelline duct, $\mathrm{U}$ - uterus. HE. 
T. B. Silva et al. HISTOLOGICAL CHARACTERIZATION OF Sticholecitha serpentis Prudhoe, 1949 (DIGENEA, BIERIIDAE, STICHOLECITHINAE), PARASITE OF Bothrops moojeni Hoge, 1966 (SERPENTES, VIPERIDAE). J. Venom. Anim. Toxins incl. Trop. Dis., 2005, 11, 4, p. 524

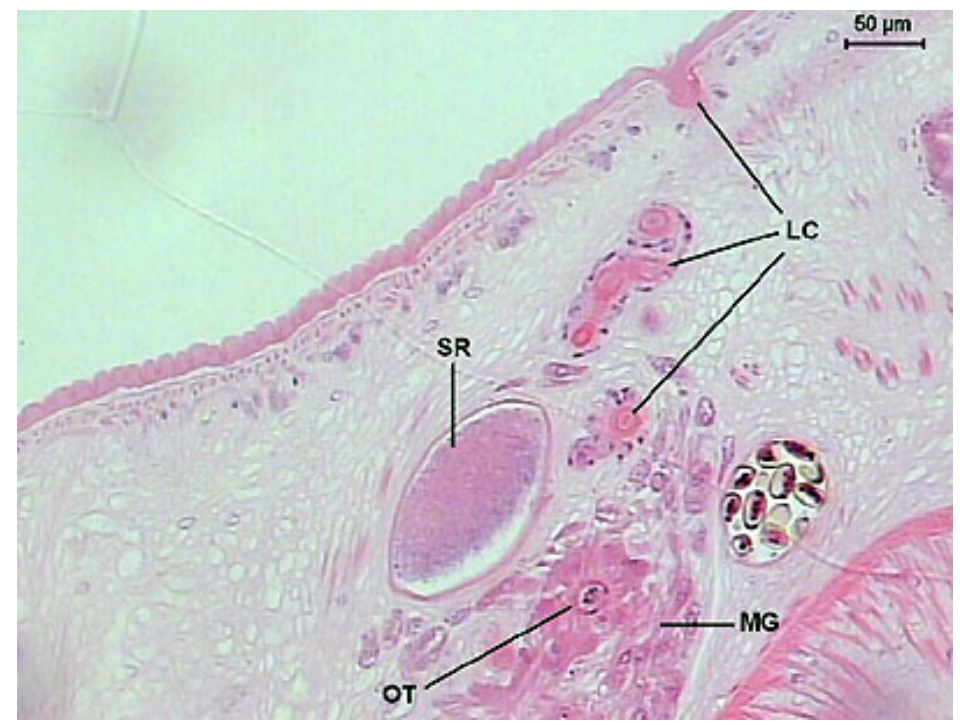

Figure 16. Transversal section of the ovary and Mehlis' gland of the Sticholecitha serpentis acetabulum. MG - Mehlis gland, SR - seminal receptacle, LC - Laurer's channel, OT - ootype. HE.

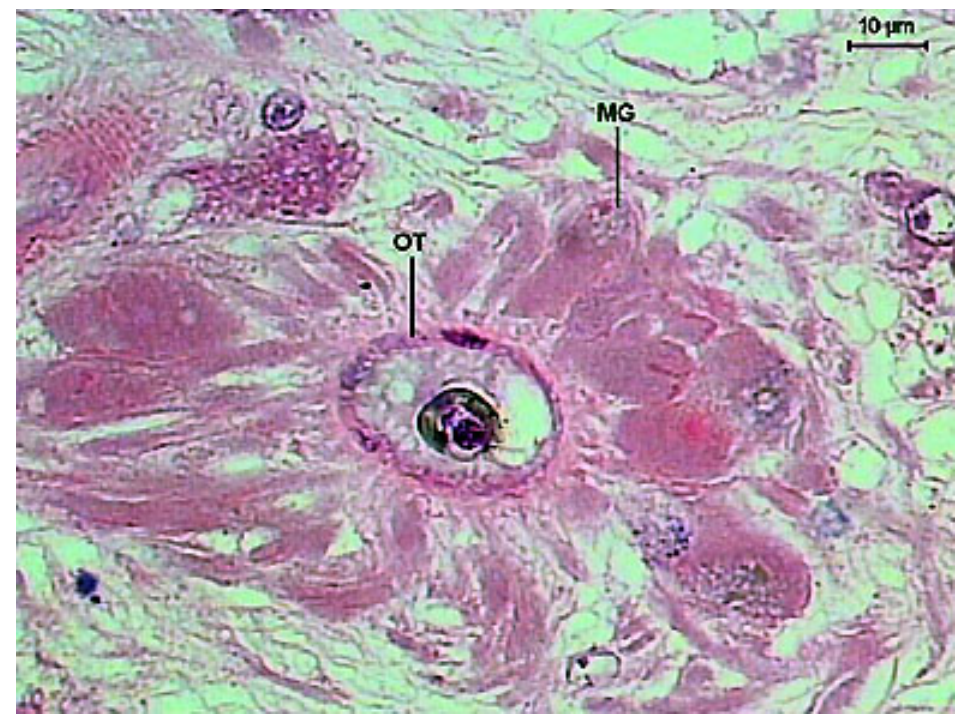

Figure 17. Detail of the Sticholecitha serpentis ootype (OT) and Mehlis' gland (MG). $\mathrm{HE}$. 
T. B. Silva et al. HISTOLOGICAL CHARACTERIZATION OF Sticholecitha serpentis Prudhoe, 1949 (DIGENEA, BIERIIDAE, STICHOLECITHINAE), PARASITE OF Bothrops moojeni Hoge, 1966 (SERPENTES, VIPERIDAE). J. Venom. Anim. Toxins incl. Trop. Dis., 2005, 11, 4, p. 525

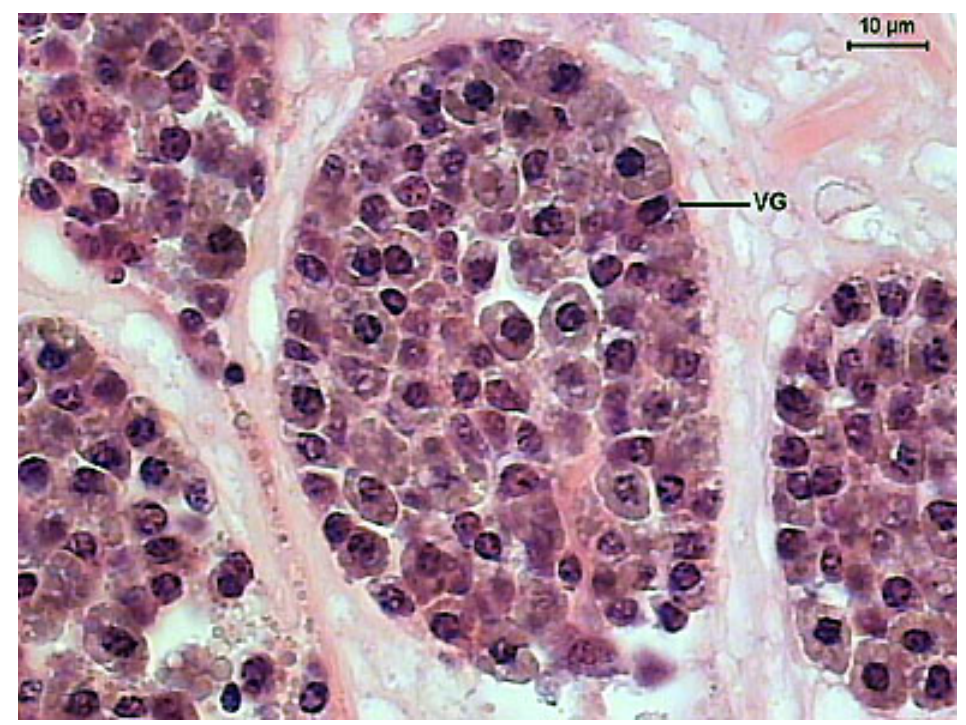

Figure 18. Detail of the Sticholecitha serpentis vitelline glands (VG). HE.

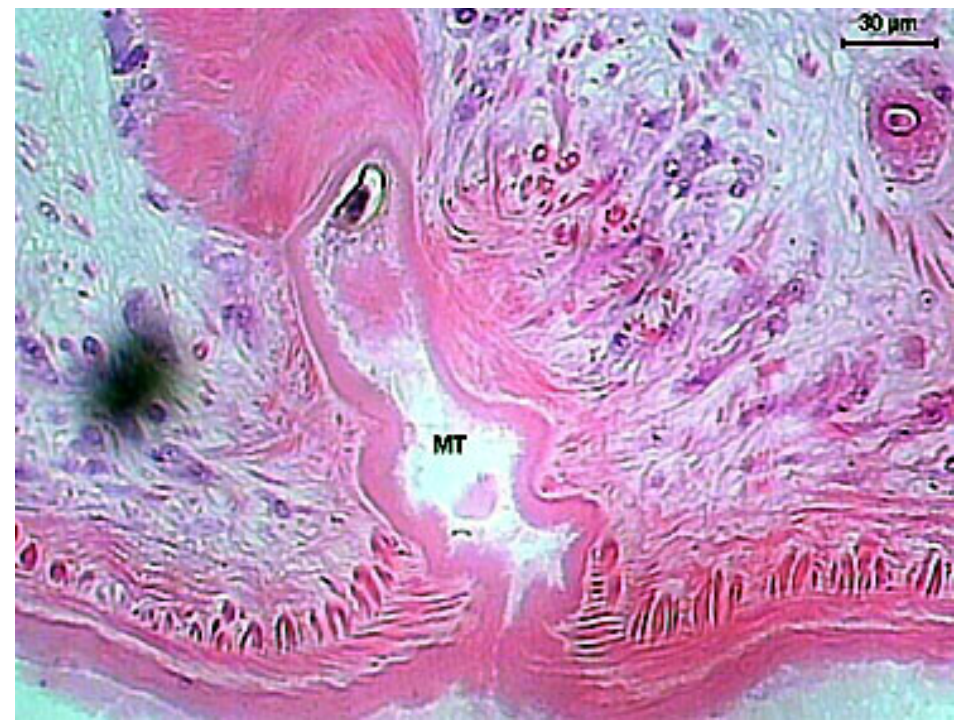

Figure 19. Transversal section of the Sticholecitha serpentis metraterm (MT). HE. 
T. B. Silva et al. HISTOLOGICAL CHARACTERIZATION OF Sticholecitha serpentis Prudhoe, 1949 (DIGENEA, BIERIIDAE, STICHOLECITHINAE), PARASITE OF Bothrops moojeni Hoge, 1966 (SERPENTES, VIPERIDAE). J. Venom. Anim. Toxins incl. Trop. Dis., 2005, 11, 4, p. 526

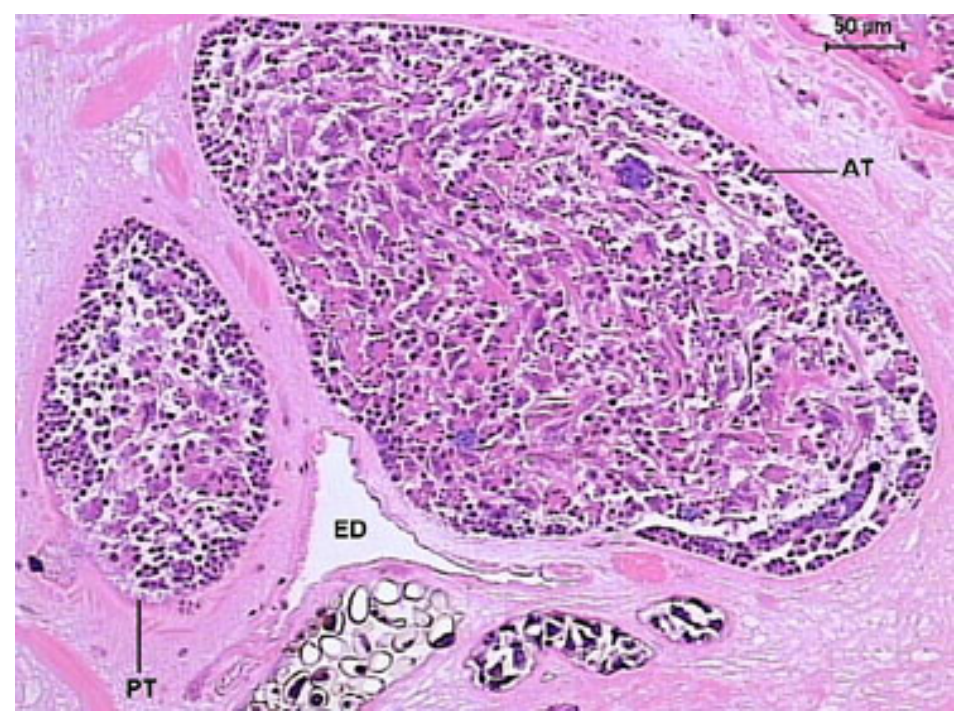

Figure 20. Transversal section of the Sticholecitha serpentis testicles. AT - anterior testicle, PT - posterior testicle, ED - excretory duct. HE.

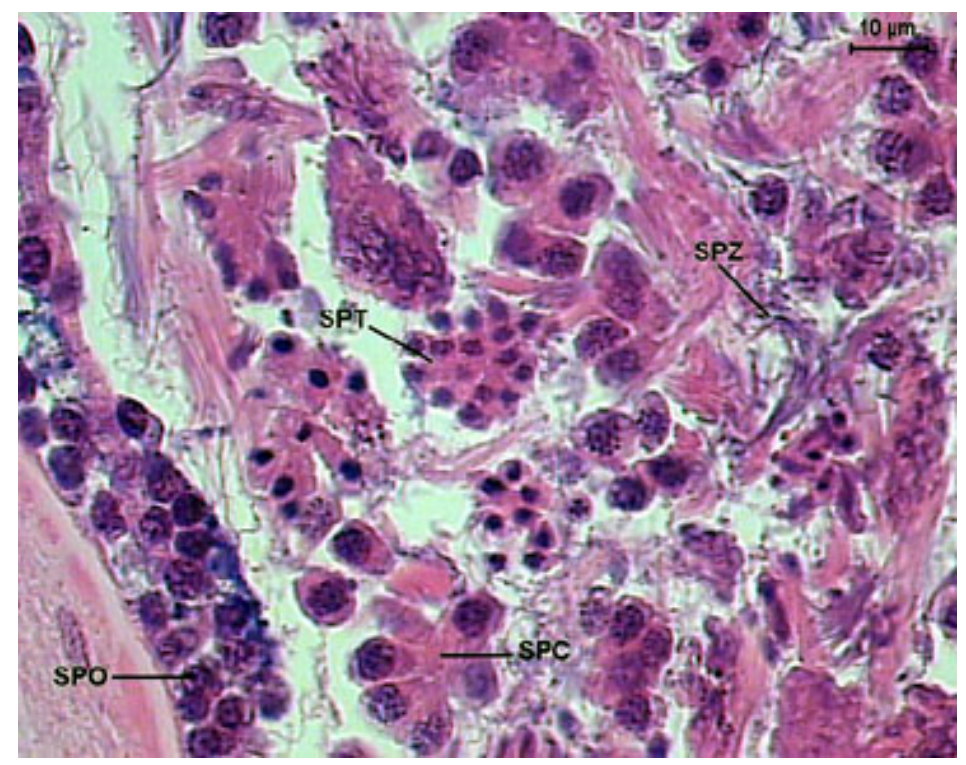

Figure 21. Detail of the Sticholecitha serpentis testicles. SPO - spermatogonia, SPC - spermatocytes, SPT - spermatids, SZP - spermatozoa. HE. 
T. B. Silva et al. HISTOLOGICAL CHARACTERIZATION OF Sticholecitha serpentis Prudhoe, 1949 (DIGENEA, BIERIIDAE, STICHOLECITHINAE), PARASITE OF Bothrops moojeni Hoge, 1966 (SERPENTES, VIPERIDAE). J. Venom. Anim. Toxins incl. Trop. Dis., 2005, 11, 4, p. 527

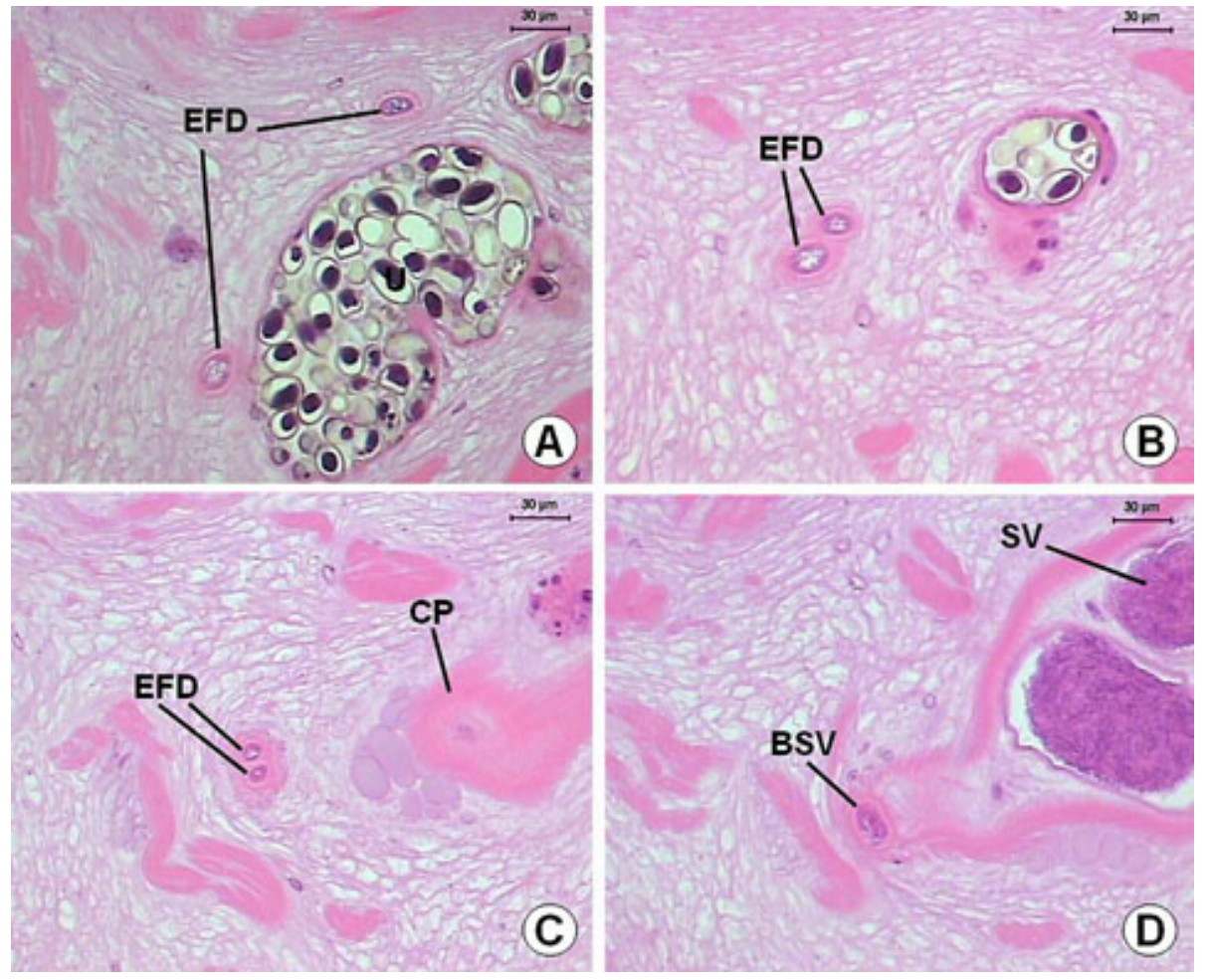

Figure 22. A-C) Detail of the Sticholecitha efferent duct. EFD - efferent duct, CP cirrus pouch, BSV - beginning of the seminal vesicle inside the cirrus pouch, SV Seminal vesicle. HE.

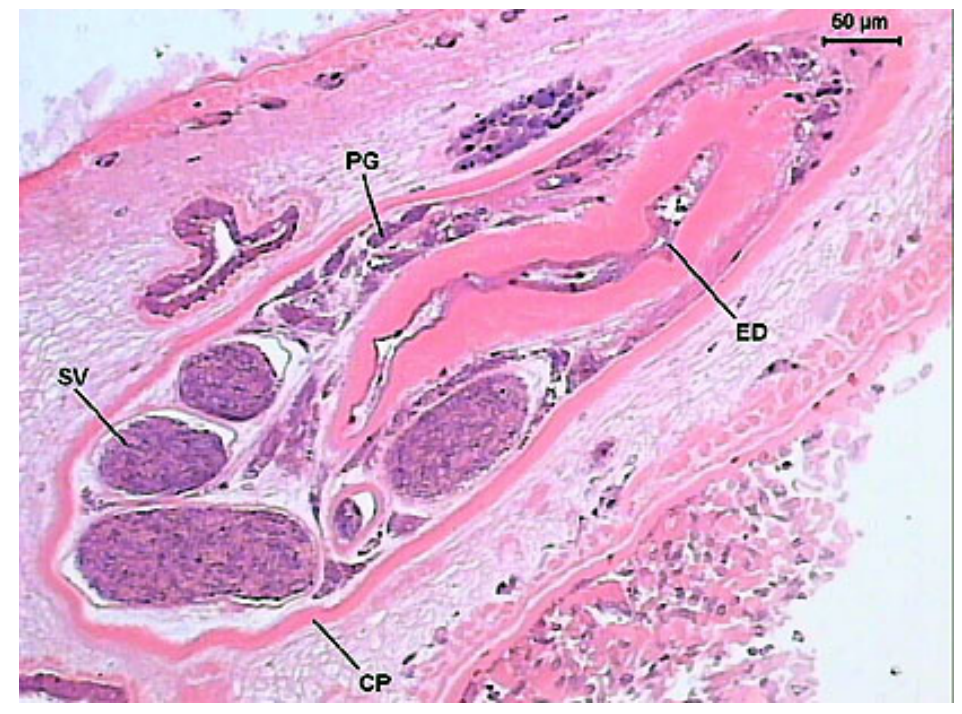

Figure 23. Transversal section of the Sticholecitha serpentis cirrus pouch. CP cirrus pouch, ED - espermatic duct, PG - prostatic glands, SV - seminal vesicle. HE. 
T. B. Silva et al. HISTOLOGICAL CHARACTERIZATION OF Sticholecitha serpentis Prudhoe, 1949 (DIGENEA, BIERIIDAE, STICHOLECITHINAE), PARASITE OF Bothrops moojeni Hoge, 1966 (SERPENTES, VIPERIDAE). J. Venom. Anim. Toxins incl. Trop. Dis., 2005, 11, 4, p. 528

\section{DISCUSSION}

The S. serpentis species was described by Prudhoe (9). In an important systematic review, Skrjabin (14) also supplied a description of this species. Travassos et al. (15), in a review on Brazilian trematodes, placed that species in the family Sticholecithidae and Artigas and Perez (2), revising that group, included S. serpentis in the subfamily Sticholecithinae, family Bieriidae. Later, Corrêa (5) agreed with the position of this species in the family Bieriidae, subfamily Sticholecithinae, and reinforced the need of information to accept the Travassos et al. (15) proposal. Published papers in the literature report the occurrence of $S$. serpentis in C. carinatus (9), $X$. severus (5) and B. moojeni (4). No other study has been published with this trematode species, mainly in relation to its morphology. Therefore, the present study contributes to this subject.

The comparison of the results obtained in the present study with the descriptions of the literature shows that histological analysis allows a good characterization of this species. In addition, the morphometric analysis accomplished with histological sections, supplied compatible values with the description of the species reported by Prudhoe (9) and Skrjabin (14). We were further able to perform the morphometry in other structures, whose measurements are not presented in the descriptions available in the literature, among them, thickness of the tegument; thickness of the different muscular layers of the oral sucker, pharynx, pre-pharynx, esophagus, acetabulum; efferent ducts; Mehlis' gland; seminal vesicle and cirrus pouch.

Another aspect to be reported is that the histological analysis showed that the structures described in the present study are compatible with the trematodes described in the literature (7).

In addition, we were able to describe the morphology of some structures that are not easily visualized in total preparations. The description of Prudhoe (9) does not report, for instance, the structure of the tegument, the ootype, the efferent ducts, and the non existence, in that species, of a defferent duct.

The results obtained in this study showed that it is possible to characterize a trematode even with non-compressed fixed specimens. Barrella and Silva (4) evaluated the infection for digenetic trematodes parasites of oral cavity and esophagus in a population of $B$. moojeni and had difficulty in characterizing the trematode species involved in the parasitism because they were not compressed 
T. B. Silva et al. HISTOLOGICAL CHARACTERIZATION OF Sticholecitha serpentis Prudhoe, 1949 (DIGENEA, BIERIIDAE, STICHOLECITHINAE), PARASITE OF Bothrops moojeni Hoge, 1966 (SERPENTES, VIPERIDAE). J. Venom. Anim. Toxins incl. Trop. Dis., 2005, 11, 4, p. 529

before fixation. Cases like this could easily be solved with the use of histological procedures.

Histology is also a useful methodology to provide information on the reproduction and feeding habits of trematodes. Silva (10) reported the copulation of Opisthogonimus fonsecai Ruiz \& Leão 1942 and described the morphology of the cirrus and metraterm of copulants. Silva (11) used histology to demonstrate that Opisthogonimus lecithonotus Luehe 1900 may use blood as food and discuss the implications of this feeding habit in the host snake. However no data regarding these subjects was available for $S$. serpentis.

The methodology used in this study should be applied to analyze the morphology of trematodes parasites of animals previously fixed in their hosts in herpetological collections. It is known that many herpetologists fixed fish, amphibians and reptiles and deposit them in scientific collections. Usually, the parasites present in those hosts are fixed incorrectly, hindering the classic methodology for the preparation of trematodes. In these cases, the histological procedures could also be a useful tool for the identification of the parasites.

Histological procedures are an important methodology to evaluate trematode morphology. However, this does not substitute the classic methodology, in which these helminths were fixed after compression and studied in total preparations. Histological analysis should be understood as a complementary methodology. Each one of these procedures is important, since they supplies a different kind of information that, when taken together, may contribute to a better characterization of the trematode species.

\section{ACKNOWLEDGMENTS}

The authors wish to thank the Fundação de Apoio a Pesquisa do Estado de São Paulo - FAPESP, for the grants to Thiago Buosi Silva (Process 01/09994-1) and Reinaldo José da Silva (Process 01/01592-1). 
T. B. Silva et al. HISTOLOGICAL CHARACTERIZATION OF Sticholecitha serpentis Prudhoe, 1949 (DIGENEA, BIERIIDAE, STICHOLECITHINAE), PARASITE OF Bothrops moojeni Hoge, 1966 (SERPENTES, VIPERIDAE). J. Venom. Anim. Toxins incl. Trop. Dis., 2005, 11, 4, p. 530

\section{REFERENCES}

1 ARTIGAS PT., CAMPOS MS. Considerações sobre Plagiorchis luehei, Travassos, 1927 (= Microderma luhei Mehra, 1931) (Trematoda, Plagiorchiidae), parasito de Hydrodynastes gigas Drum. et Brib. (Reptilia, Colubridae). Mem. Inst. Butantan, 1977, 40/41, 265-79.

2 ARTIGAS PT., PEREZ MD. Sistemática dos Opisthogonimidae (Trematoda, Plagiorchoidea). Criação da família Bieriidae N. Fam. Mem. Inst. Butantan, 1969, 34, 97-110.

3 BANCROFT JD., STEVENS A. Theory and practice of histological techniques. 3.ed. Edinburgh: Churchill Livingstone, 1991. 726p.

4 BARRELLA TH., SILVA RJ. Digenetic trematodes infection in a Bothrops moojeni (Viperidae) population from a fauna rescue in Porto Primavera, São Paulo State. Arq. Bras. Med. Vet. Zootec., 2003, 55, 243-5.

5 CORREA AAS. Fauna de trematódeos parasitos de ofídios da área geográfica brasileira. São Paulo: Universidade de São Paulo, Instituto de Ciências Biomédicas, 1980. 177p. [Masters Dissertation].

6 CORREA FMA., PAULINO RC., BUONONATO MA., FEDERSONI Jr PA. Ochetosoma heterocoelium (Travassos, 1921) (Trematoda: Digenea: Ochetosomatidae) em novo hospedeiro. Mem. Inst. Butantan, 1990, 52, 11-6.

7 LEAKE LD. Comparative histology: an introduction to the microscopic structure of animals. London; New York: Academic Press, 1975. 738p.

8 McMANUS JFA., MOWRY RW. Staining Methods, histologic and histochemical. New York: Hoeber, 1960. 423p.

9 PRUDHOE S. Some roundworms and flatworms from the West Indies and Surinam. III - Trematodes. J. Linn. Soc. Lond. (Zool.), 1949, 41, 415-9.

10 SILVA RJ. Copulation of Opisthogonimus fonsecai Ruiz \& Leão, 1942 (Trematoda, Digenea, Plagiorchiidae) parasite of Bothrops moojeni Hoge, 1966 (Serpentes, Viperidae). J. Venom. Anim. Toxins incl. Trop. Dis., 2005, $11,68-75$.

11 SILVA RJ. Note on the feeding habits of Opisthogonimus lecithonotus (Trematoda, Digenea, Plagiorchiidae). Parasitol. Res., 2004, 94 (6), 471-2. 
T. B. Silva et al. HISTOLOGICAL CHARACTERIZATION OF Sticholecitha serpentis Prudhoe, 1949 (DIGENEA, BIERIIDAE, STICHOLECITHINAE), PARASITE OF Bothrops moojeni Hoge, 1966 (SERPENTES, VIPERIDAE). J. Venom. Anim. Toxins incl. Trop. Dis., 2005, 11, 4, p. 531

12 SILVA RJ., BARRELLA TH. Micrurus frontalis as a new host recorded for Haplometroides odhneri (Trematoda, Digenea, Plagiorchiidae). Rev. Bras. Parasitol. Vet., 2002, 11, 47-8.

13 SILVA RJ., RODRIGUES RR., STEIN MFB., SIPOLI GPM., PINHÃO R., LOPES

CAM. The detection of Ochetosoma heterocoelium (Travassos, 1921) (Trematoda: Digenea: Ochetosomatidae) in Chironius exoletus (Linnaeus, 1758) (Ophidia: Colubridae). J. Venom. Anim. Toxins, 1999, 5, 85-90.

14 SKRJABIN KI. Trematodes of animals and man. Jerusalém: c1965. 532p.

15 TRAVASSOS L., FREITAS JFT., KOHN A. Trematódeos do Brasil. Mem. Inst. Oswaldo Cruz, 1969, 67, 1-886.

16 VELLÁSQUEZ-MALDONADO JJ. Estudo taxonômico dos trematódeos paranfistomiformes do rúmen de bovinos do Estado do Rio Grande do Sul. Porto Alegre: Universidade Federal do Rio Grande do Sul, Faculdade de Veterinária, 1976. 86p. [Masters Dissertation]. 